\title{
Microbiological Quality Assessment of Unbranded Groundnut Oil Sold in Major Markets in Port Harcourt City, Rivers State, Nigeria
}

\author{
Austin A. Okwelle* and Faith Chinasa Nwabueze
}

\author{
Department of Biological Sciences (Microbiology Unit), Faculty of Natural and Applied \\ Sciences, Ignatius Ajuru University of Education Rumuolumeni, P. M. B 5047, \\ Port Harcourt, Rivers State, Nigeria
}

*Corresponding author

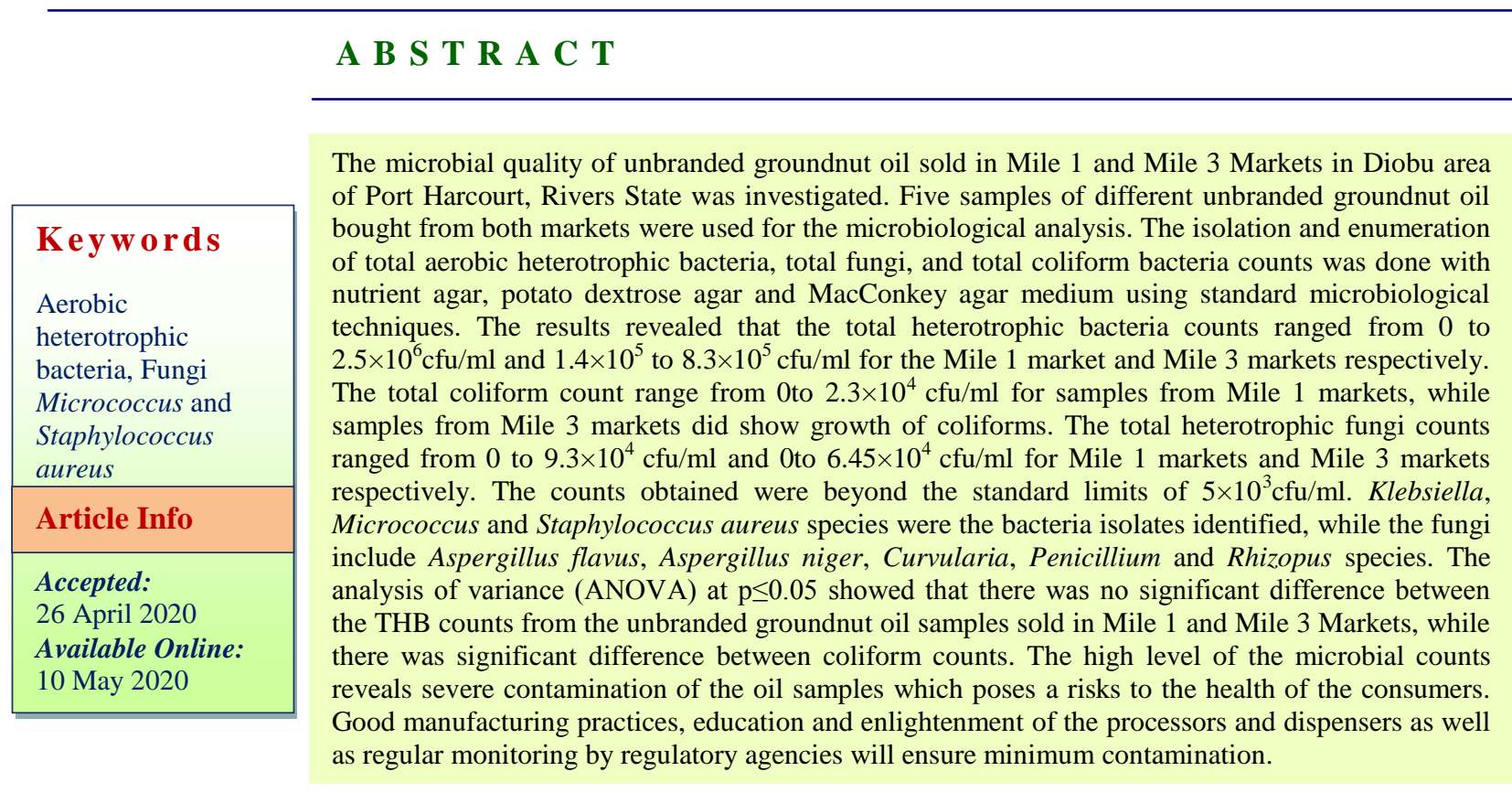

\section{Introduction}

According to Atasie et al., (2009), groundnut (Arachis hypogea) or peanut is a member of the Fabaceae family, native of South and Central America. Though groundnuts are legumes, they are the most commonly eaten "nut" in the world. The groundnut oil, also known as peanut oil or Arachis oil is light yellow transparent edible oil with clear colour, pleasant fragrance and good taste that can digest very easily (ABC Machinery, 2019). Groundnuts are usually enriched with some essential nutrients that play beneficial 
roles to human health. Onawo and Adamu, (2018) stated that groundnut oil is one of the most important group of oil and is normally used to reduce cholesterol and prevent heart disease. Eshun et al., (2013) reported that the risk of heart disease can be significantly lowered when groundnut oil, groundnut or groundnut butter is consumed daily. Nkafamiya et al., (2010) and Mandloi et al., (2014) noted that Pharmaceutical companies now incorporate groundnut oil in formulations for the production of various products intended for internal and external use.

Groundnut oil is a vegetable which contains only a small proportion of non-glyceride constituents. According to Hati et al., (2009), unbranded vegetable oil (UVO) are those locally produced and laboratory extracted edible vegetable oils that are branded. Edible oil is one of the most valuable and widely used processed foods Tesfaye et al., (2015). Vegetable oils are consumed domestically in Nigeria. Babatunde and Bello, (2016) reported the major sources of edible oils in Nigeria are groundnut and palm oil. These vegetable oils are used mainly as cooking oils, salad oil and for the production of soap, margarine and cosmetics. Therefore, the quality of the oil and its stability are two critical requirements for the consumers and the food processing industries (Wali et al., 2015).

Vegetable oils contributes significantly to the improvement of the diet, providing a good source of lipid and fatty acids for human nutrition and functioning to repair worn out tissues, formation new cells as well as source of energy supply (Babatunde and Bello, 2016).According to Nkafamiya et al., (2010), groundnut oil contains much potassium than sodium and is a good source for calcium, phosphorus and magnesium. The demand and consumption of unbranded groundnut oil has increased rapidly in recent time.
This may been influenced by the regular availability, accessibility and low cost of groundnut oil. There are basically four methods used for the production of groundnut oil, including pressing, solvent extraction, aqueous extraction, and aqueous enzymatic methods (ABC Machinery, 2019). Many people who use the traditional method of production for the extraction of edible oil have neither little nor no knowledge of the current production techniques nor the microbiological implication of engaging in unhygienic sanitary practises and employing poor storage methods.

Mandloi et al., (2014) stated that the most essential characteristics of oils are the chemical properties, which constitute one of the vital components of balanced diet. Groundnut oil is composed of more than $80 \%$ unsaturated fatty acids such as oleic acid $(41.2 \%)$ and $37.6 \%$ linoleic acid $(37.6 \%)$. It is also contains $19.9 \%$ of palmitic acid, stearic acid, arachidic acid and other unsaturated fatty acids (ABC Machinery, 2019).

The fatty acid composition of peanut oil is relatively good and easily digested and absorbed by the human body. Nkafamiya et al., (2010) in a study have found that groundnut oil contains more potassium than sodium, and a very good source of calcium, phosphorus and magnesium. Its content also includes thiamine, vitamin $\mathrm{E}$, selenium, zinc and arginine. Barku et al., (2012) noted that edible oils represent the highest source of energy per unit weight consumed notwithstanding the origin (animal, vegetable or marine).

Groundnut oil undergoes rancidity, which is the complete or incomplete oxidation or hydrolysis of fats and oils when exposed to air, light, or moisture or by bacterial action, resulting in unpleasant taste and odour. When these processes occur in food, undesirable 
odours and flavours occur. Sunlight catalyses the reaction, this is due to nature of the freeradical reactions (Sergey, 2014). This breakdown is as a result of lipases, a class of hydrolases primarily responsible for hydrolysis of acyglycerides. Many microorganisms such as bacteria, yeasts, moulds and a few protozoa are known to secrete lipases for the digestion of lipid materials (Nagarajan, 2012; Abrunhosa et al., 2013). Often times they are contaminated by mycotoxins and heavy metals ( $\mathrm{Ma}$ et al., 2015). The main aim of this study is to evaluate the microbiological quality of unbranded groundnut oils sold in two major markets in Port Harcourt city, Rivers State.

\section{Materials and Methods}

\section{The study area}

The study was carried out within the Diobu area of Port Harcourt city, Rivers State where the major markets are located.

\section{Sampling sites}

The two major markets selected for this study are the popular Mile 1 (Rumuwoji) Market and Mile 3 (Oroworukwo) Market. These markets are the major places where unbranded groundnut oil marketing takes place. The GPS coordinates of Mile 1 Market is Lattitude $4^{\circ} 471^{\prime} .287376 " \mathrm{~N}$ and Longitude 6 59'53.7756" E, while Mile 3 Market had coordinate of Latitude 4'48'8.0604' $\mathrm{N}$ and Longitude 659'27.3912”E (Figure 1).

\section{Collection of samples}

Five samples of the unbranded groundnut oil were bought from the vendors from each of the Mile 1 and Mile 111 markets, making a total of ten (10) samples. All the samples were collected in already labelled $100 \mathrm{ml}$ sterile bottles and transported to the Biology
Department Laboratory, Ignatius Ajuru University of Education for microbiological analysis.

Microbiological analysis of groundnut oil samples: isolation and enumeration of total heterotrophic bacteria

Nutrient Agar, MacConkey Agar and Sabouraud Dextrose Agar (SDA) media were used for the isolation and enumeration of total heterotrophic bacteria, total coliform bacteria and total fungal counts respectively. Preparation of the media was according to the manufacturers instructions. The bacterial isolates were identified on the basis of their cultural, morphological and physiological characteristics in accordance with the schemes and methods described by Holt et al., (1994), Fawole and Oso (1995) and Cheeseborough (2006). The standard identification keys and atlas of De Hoog et al., (2000) and Tsuneo, (2010) was used to characterise and identify the fungal isolates based on their macroscopic and microscopic features. The data obtained from the colony counts was subjected to Analysis of Variance(ANOVA).

\section{Results and Discussion}

The results of the total aerobic heterotrophic bacteria (THB), total coliform and total fungal counts obtained from analysis of the unbranded groundnut oil samples in mile 1and mile 3 markets are presented on the tables 1-12 and figures 1-3.

The focus of this study was to evaluate the microbiological quality of unbranded groundnut oil sold in two major markets (Mile 1 and Mile 3 markets) in the Diobu area of Port Harcourt city, Rivers State. This is because the microbiological contamination of edible oils is very prevalent in most areas and poses a great health risks to the unsuspecting 
consumers. Tesfaye et al., (2015) reported that the issue of microbial contamination is commonly observed in many edible oil markets. The result of the study shows that the total heterotrophic bacteria (THB) counts ranged between $0 \mathrm{cfu} / \mathrm{ml}$ to $2.5 \times 10^{6} \mathrm{cfu} / \mathrm{ml}$ and $1.4 \times 10^{5} \mathrm{cfu} / \mathrm{ml}$ to $8.3 \times 10^{5} \mathrm{cfu} / \mathrm{ml}$ for Mile 1 Market and Mile 3 Market respectively.

Although, the total heterotrophic bacteria counts were higher in mile 3 market than in mile 1 market, the analysis of variance (ANOVA) at $\mathrm{p} \leq 0.05$ showed that there was no significant difference between the THB counts from the unbranded groundnut oil samples sold in Mile 1 and Mile 3 Markets. However, the THB counts are higher than the (4.53 to $\left.12.13 \times 10^{3} \mathrm{cfu} / \mathrm{ml}\right)$ reported by Tesfaye et al., (2015). The high bacterial load could be due to the unhygienic nature of the market, oil component, storage facility available and the storage conditions (Okechalu et al., 2011).

The total coliform counts ranged from 0 $\mathrm{cfu} / \mathrm{ml}$ to $2.3 \times 10^{4} \mathrm{cfu} / \mathrm{ml}$ in mile 1 market, while no coliforms was detected from the samples in mile 3 market. According to Chabiri et al., (2009), edible oils do not exhibit significant growth of the coliform bacteria. This may probably account for the absence of coliforms in samples from mile 3markets.

The analysis of variance (ANOVA) at $p \leq 0.05$ of coliforms counts indicates that there was a significant difference between the coliform from samples in Mile 1 and Mile 3 Markets. For total heterotrophic fungi (THF), the counts ranged between $0 \mathrm{cfu} / \mathrm{ml}$ and $9.3 \times 10^{4} \mathrm{cfu} / \mathrm{ml}$, and $0 \mathrm{cfu} / \mathrm{ml}$ to $6.45 \times 10^{4}$ $\mathrm{cfu} / \mathrm{ml}$ for mile 1 markets and mile 3 markets respectively. The differences in fungal counts may be due to the inability of the fungal species to effectively metabolise the oil. The analysis of variance (ANOVA) at $p \leq 0.05$ of THF counts reveals that there was no significant difference between the THF counts obtained from unbranded groundnut oil samples sold in mile 1 and mile 3 markets.

The bacterial isolates identified in the study include Micrococcus sp, Klebsiella sp. and Staphylococcus aureus. Tesfaye et al., (2015), in a study had also identified similar bacteria species. The fungi identified are Aspergillus flavus, Aspergillus niger, Curvularia, Penicillium and Rhizopus species. Sylvester and Eligha (2013) and Flora et al., (2018) reported the isolation of similar fungal species. Tobin-West et al., (2018) also isolated and identified Aspergillus, Penicilium, Mucor, Rhizopus and Fusarium species as the major fungal species associated with raw groundnut seeds sold in Port Harcourt metropolis.

According to CDC, (2006) the Aspergillus species isolated from the vegetable oils have shown ability to produce Aflatoxin B1, B2, G1 and G2 in in-vitro studies. There is also the probability of acquiring food borne disease due to consumption of the groundnut oil products contaminated with Staphylococcus aureus. It could cause gastroenteritis in the consumers especially when the groundnut oil is eaten raw. Faecal contamination of the product leads to the occurrence of coliforms, which isa good indicator of food spoilage (Dubey and Maheshwar, 2003). In terms of prevalence, Staphylococcus aureus $(78.2 \%)$ and Micrococcus (69.9\%) had the highest prevalence rate for the bacteria species, while for the fungi, Aspergillusflavus (47.1\%) had the highest prevalence followed by Rhizopus species. The prevalence of these organisms is a reflection of the poor conditions of the markets and the unhygienic practices adopted by the processors and vendors. 
Table.1 Total heterotrophic bacteria counts in unbranded groundnut oils samples sold in Mile 1 Market

\begin{tabular}{|c|c|c|c|c|c|}
\hline SI & \multicolumn{5}{|c|}{ Total Heterotrophic Bacteria Count (cfu/ml) } \\
\hline & M1M1 & M1M2 & M1M3 & M1M4 & M1M5 \\
\hline $\mathbf{1}^{\text {st }}$ & $1.25 \times 10^{5}$ & $2.50 \times 10^{6}$ & $1.49 \times 10^{5}$ & $2.83 \times 10^{5}$ & $1.00 \times 10^{5}$ \\
\hline $2^{\text {nd }}$ & $1.00 \times 10^{5}$ & $1.12 \times 10^{5}$ & $1.41 \times 10^{5}$ & $2.92 \times 10^{5}$ & $9.50 \times 10^{5}$ \\
\hline $3^{\text {rd }}$ & - & $1.02 \times 10^{5}$ & $1.38 \times 10^{5}$ & $2.80 \times 10^{5}$ & $1.05 \times 10^{5}$ \\
\hline
\end{tabular}

SI - sampling instances; M1M1 - Mile 1, market 1, M1M2 - Mile 1, market 2; M1M3 - Mile 1, market 3; M1M4 - Mile 1, market 4; M1M5 - Mile 1, market 5

Table.2 Total heterotrophic bacteria counts in unbranded groundnut oil samples sold in Mile 3 Market

\begin{tabular}{|c|c|c|c|c|c|c|}
\hline SI & \multicolumn{5}{|c|}{ Total Heterotrophic Bacteria Count (cfu/ml) } \\
\hline & M3M1 & M3M2 & M3M3 & M3M4 & M $3 \mathrm{M} 5$ \\
\hline $\mathbf{1}^{\text {st }}$ & $2.55 \times 10^{5}$ & $1.50 \times 10^{5}$ & $1.48 \times 10^{5}$ & $8.30 \times 10^{5}$ & $7.30 \times 10^{5}$ \\
\hline $\mathbf{2}^{\text {nd }}$ & $2.00 \times 10^{5}$ & $1.55 \times 10^{5}$ & $1.50 \times 10^{5}$ & $8.00 \times 10^{5}$ & $6.50 \times 10^{5}$ \\
\hline $\mathbf{3}^{\text {rd }}$ & $2.80 \times 10^{5}$ & $1.49 \times 10^{5}$ & $1.40 \times 10^{5}$ & $7.80 \times 10^{5}$ & $7.00 \times 10^{5}$ \\
\hline
\end{tabular}

SI - sampling instances; M3M1 - Mile 3, market 1, M3M2 - Mile 3, market 2; M3M3 - Mile 3, market 3; M3M4 - Mile 3, market 4; M3M5 - Mile 3, market 5

Table.3 Analysis of variance (ANOVA) of THB counts in sampled unbranded groundnut oil sold in Mile 1 and Mile 3 Markets

\begin{tabular}{|c|c|c|c|c|c|}
\hline \multicolumn{5}{|c|}{ SUMMARY } \\
\hline $\begin{array}{c}\text { Groups } \\
\begin{array}{c}\text { Means for Mile 1 } \\
\text { markets }\end{array}\end{array}$ & Count & Sum & Average & \multicolumn{2}{|c|}{ Variance } \\
\hline $\begin{array}{c}\text { Means for Mile 3 } \\
\text { markets }\end{array}$ & 3 & $1.08 \times 10^{6}$ & $3.58 \times 10^{5}$ & $6.53 \times 10^{10}$ \\
\hline \multicolumn{7}{|c|}{} & $1,22 \times 10^{6}$ & $4.08 \times 10^{5}$ & $2.53 \times 10^{8}$ \\
\hline Source of Variation & SS & DNOVA & MS & $\mathrm{F}_{\text {cal. }}$ & $\mathrm{F}_{\text {tab. }}$ \\
\hline Between Groups & $3.65 \times 10^{9}$ & 1 & $3.65 \times 10^{9}$ & $0.1114^{\text {ns }}$ & 7.7086 \\
\hline Within Groups & $1.31 \times 10^{11}$ & 4 & $3.28 \times 10^{10}$ & & \\
\hline Total & $1.35 \times 10^{11}$ & 5 & & & \\
\hline
\end{tabular}

SS - Sum of squares, $d f$ - degree of freedom, MS - Mean square, $F_{\text {cal. }}-F$ calculated, $F_{\text {tab }}-F$ tabulated

Table.4 Total coliform counts in unbranded groundnut oils samples sold in Mile 1 market

\begin{tabular}{|c|c|c|c|c|c|}
\hline SI & \multicolumn{5}{|c|}{ Coliform Count (cfu/ml) } \\
\hline & M1M1 & M1M2 & M1M3 & M1M4 & M1M5 \\
\hline $\mathbf{1}^{\text {st }}$ & $1.00 \times 10^{4}$ & - & $2.50 \times 10^{4}$ & $1.60 \times 10^{4}$ & - \\
\hline $\mathbf{2}^{\text {nd }}$ & $1.40 \times 10^{4}$ & - & $1.80 \times 10^{4}$ & $1.30 \times 10^{4}$ & - \\
\hline $3^{\text {rd }}$ & $1.10 \times 10^{4}$ & - & $2.00 \times 10$ & $1.00 \times 10^{4}$ & - \\
\hline
\end{tabular}

SI - sampling instances; M1M1 - Mile 1, market 1, M1M2 - Mile 1, market 2; M1M3 - Mile 1, market 3; M1M4 - Mile 1, market 4; M1M5 - Mile 1, market 5 
Table.5 Total coliform counts in sampled unbranded groundnut oils sold in Mile 3 Markets

\begin{tabular}{|c|c|c|c|c|c|}
\hline SI & \multicolumn{5}{|c|}{ Coliform Count (cfu/ml) } \\
\hline & M1M1 & M1M2 & M1M3 & M1M4 & M1M5 \\
\hline $\mathbf{1}^{\text {st }}$ & - & - & - & - & - \\
\hline $2^{\text {nd }}$ & - & - & - & - & - \\
\hline $3^{\text {rd }}$ & - & - & - & - & - \\
\hline
\end{tabular}

SI - sampling instances; M3M1 - Mile 3, market 1, M3M2 - Mile 3, market 2; M3M3 - Mile 3, market 3; M3M4 - Mile 3, market 4; M3M5 - Mile 3, market 5

Table.6 Analysis of variance (ANOVA) of Coliform counts in sampled unbranded groundnut oil sold in Mile 1 and Mile 3 Markets

\begin{tabular}{|c|c|c|c|c|c|}
\hline \multicolumn{2}{|c|}{ SUMMARY } \\
\hline $\begin{array}{c}\text { Groups } \\
\begin{array}{c}\text { Means for Mile 1 } \\
\text { markets }\end{array}\end{array}$ & Count & Sum & Average & \multicolumn{2}{|c|}{ Variance } \\
\hline $\begin{array}{c}\text { Means for Mile 3 } \\
\text { markets }\end{array}$ & 3 & $2.34 \times 10^{4}$ & $7.80 \times 10^{3}$ & $1.00 \times 10^{7}$ \\
\hline & & 0 & 0 & 0 \\
\hline Source of Variation & SS & ANOVA & MS & $\mathrm{F}_{\text {cal. }}$ & $\mathrm{F}_{\text {tab. }}$ \\
\hline Between Groups & $9.13 \times 10^{7}$ & 1 & $9.13 \times 10^{7}$ & $18.1392^{* *}$ & 7.7086 \\
\hline Within Groups & $2.01 \times 10^{7}$ & 4 & $5.03 \times 10^{6}$ & & \\
\hline Total & $1.11 \times 10^{8}$ & 5 & & & \\
\hline
\end{tabular}

SS - Sum of squares, $\mathrm{df}-$ degree of freedom, MS - Mean square, $\mathrm{F}_{\text {cal. }}-\mathrm{F}$ calculated, $\mathrm{F}_{\text {tab }}-\mathrm{F}$ tabulated

Table.7 Total heterotrophic fungal counts in unbranded groundnut oil samples sold in Mile 1 Markets

\begin{tabular}{|c|c|c|c|c|c|}
\hline SI & \multicolumn{5}{|c|}{ Total Heterotrophic Fungal Count (cfu/ml) } \\
\hline & M1M1 & M1M2 & M1M3 & M1M4 & M1M5 \\
\hline $\mathbf{1}^{\text {st }}$ & $1.00 \times 10^{4}$ & $9.00 \times 10^{4}$ & - & $1.00 \times 10^{4}$ & $1.00 \times 10^{4}$ \\
\hline $\mathbf{2}^{\text {nd }}$ & $1.30 \times 10^{4}$ & $7.80 \times 10^{4}$ & - & $1.00 \times 10^{4}$ & $1.30 \times 10^{4}$ \\
\hline $\mathbf{3}^{\text {rd }}$ & $1.00 \times 10^{4}$ & $9.30 \times 10^{4}$ & - & $1.60 \times 10^{4}$ & $1.00 \times 10^{4}$ \\
\hline
\end{tabular}

SI - sampling instances; M1M1 - Mile 1, market 1, M1M2 - Mile 1, market 2; M1M3 - Mile 1, market 3; M1M4 - Mile 1, market 4; M1M5 - Mile 1, market 5

Table.8 Total heterotrophic fungal counts in sampled unbranded groundnut oils sold in Mile 3 Market

\begin{tabular}{|c|c|c|c|c|c|}
\hline SI & \multicolumn{5}{|c|}{ Total Heterotrophic Fungal Count (cfu/ml) } \\
\hline & M3M1 & M3M2 & M3M3 & M3M4 & M3M5 \\
\hline $\mathbf{1}^{\text {st }}$ & - & $6.30 \times 10^{4}$ & $1.00 \times 10^{4}$ & $3.00 \times 10^{4}$ & $1.00 \times 10^{4}$ \\
\hline $2^{\text {nd }}$ & - & $6.45 \times 10^{4}$ & $1.40 \times 10^{4}$ & $2.50 \times 10^{4}$ & $1.30 \times 10^{4}$ \\
\hline $3^{\text {rd }}$ & - & $6.26 \times 10^{4}$ & $1.00 \times 10^{4}$ & $3.30 \times 10^{4}$ & $1.70 \times 10^{4}$ \\
\hline
\end{tabular}

SI - sampling instances; M3M1 - Mile 3, market 1, M3M2 - Mile 3, market 2; M3M3 - Mile 3, market 3; M3M4 - Mile 3, market 4; M3M5 - Mile 3, market 5 
Table.9 Analysis of variance (ANOVA) of THF counts in sampled unbranded groundnut oil sold in Mile 1 and Mile 3 Markets

\begin{tabular}{|c|c|c|c|c|c|}
\hline \multicolumn{5}{|c|}{ SUMMARY } \\
\hline $\begin{array}{c}\text { Groups } \\
\begin{array}{c}\text { Means for Mile 1 } \\
\text { markets }\end{array}\end{array}$ & Count & Sum & Average & \multicolumn{2}{|c|}{ Variance } \\
\hline $\begin{array}{c}\text { Means for Mile 3 } \\
\text { markets }\end{array}$ & 3 & $7.36 \times 10^{4}$ & $2.42 \times 10^{4}$ & $2.28 \times 10^{6}$ \\
\hline \hline \multicolumn{7}{|c|}{ ANOVA } & & & \\
\hline Source of Variation & SS & Df & MS & $\mathrm{F}_{\text {cal. }}$ & $\mathrm{F}_{\text {tab. }}$ \\
\hline Between Groups & $7.92 \times 10^{5}$ & 1 & $7.92 \times 10^{5}$ & $0.4913^{\text {ns }}$ & 7.7086 \\
\hline Within Groups & $6.45 \times 10^{6}$ & 4 & $1.61 \times 10^{6}$ & & \\
\hline Total & $7.24 \times 10^{6}$ & 5 & & & \\
\hline
\end{tabular}

SS - Sum of squares, $\mathrm{df}-$ degree of freedom, MS - Mean square, $\mathrm{F}_{\text {cal. }}-\mathrm{F}$ calculated, $\mathrm{F}_{\text {tab }}-\mathrm{F}$ tabulated

Table.10 Identification of bacteria isolates from unbranded groundnut oil samples sold in mile and mile 3 markets

\begin{tabular}{|c|c|c|c|c|c|c|c|c|c|c|c|}
\hline $\mathbf{S} / \mathbf{N}$ & $\begin{array}{c}\text { Gram } \\
\text { Reaction }\end{array}$ & Coagulase & Catalase & $\begin{array}{c}\text { Oxidas } \\
\text { e }\end{array}$ & Indole & $\begin{array}{c}\text { Ureas } \\
\text { e }\end{array}$ & $\begin{array}{c}\text { Citrate } \\
\text { utilization }\end{array}$ & $\begin{array}{c}\text { Hydrogen } \\
\text { sulphide }\end{array}$ & $\begin{array}{c}\text { Motility } \\
\text { test }\end{array}$ & Lactose & Bacterial isolate \\
\hline 1 & $+\mathrm{ve}$ & -ve & -ve & -ve & -ve & -ve & -ve & -ve & $\begin{array}{l}\text { Non- } \\
\text { motile }\end{array}$ & - & Micrococcus sp. \\
\hline 2 & $+v e$ & -ve & + ve & -ve & -ve & -ve & -ve & -ve & $\begin{array}{l}\text { Non- } \\
\text { motile }\end{array}$ & - & $\begin{array}{c}\text { Coagulase- } \\
\text { veStaphylococcus sp. }\end{array}$ \\
\hline 3 & +ve & +ve & +ve & -ve & -ve & -ve & +ve & -ve & $\begin{array}{l}\text { Non- } \\
\text { motile }\end{array}$ & - & $\begin{array}{c}\text { Staphylococcus } \\
\text { aureus }\end{array}$ \\
\hline 4 & -ve & -ve & -ve & -ve & -ve & -ve & -ve & -ve & $\begin{array}{l}\text { Non- } \\
\text { motile }\end{array}$ & + & Klebsiellasp. \\
\hline
\end{tabular}

N/B: +ve (positive), -ve (negative)

Table.12 Macroscopic identification of fungi isolates from unbranded groundnut oil samples sold in mile 1 and mile 3 Markets

\begin{tabular}{|c|c|}
\hline Macroscopic Characterization and Texture & Inference Fungi \\
\hline $\begin{array}{c}\text { Green fungal colony that later turned greenish - yellow or pale } \\
\text { green }\end{array}$ & Aspergillusflavus \\
\hline Wooly velvet, whitish m colour but later turned fungal black & Aspergillusniger \\
\hline $\begin{array}{l}\text { Wooly colonies, the colour of the colony is white to pinkish gray } \\
\text { initially and turns to olive brown or black }\end{array}$ & Curvulariasp. \\
\hline $\begin{array}{c}\text { Powdery whitish surface but later turned blush-green whitish } \\
\text { reverse sides and edges }\end{array}$ & Penicilliumsp. \\
\hline Creamy powder growth that later turned black & Rhizopussp. \\
\hline
\end{tabular}




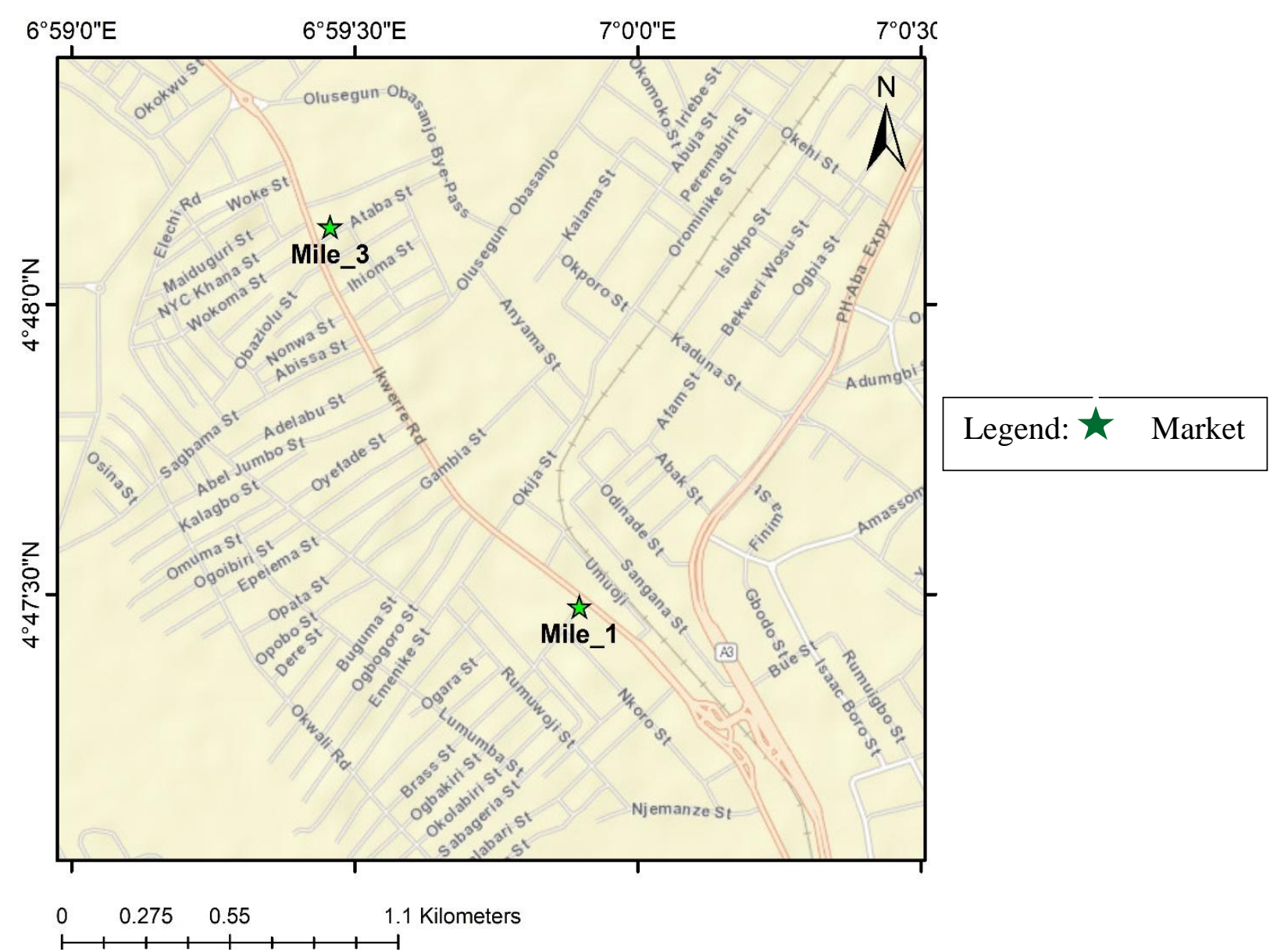

Figure.1 Map of Port Harcourt City Local Government Area showing the GPS coordinates of Mile 1 and Mile 3 Market

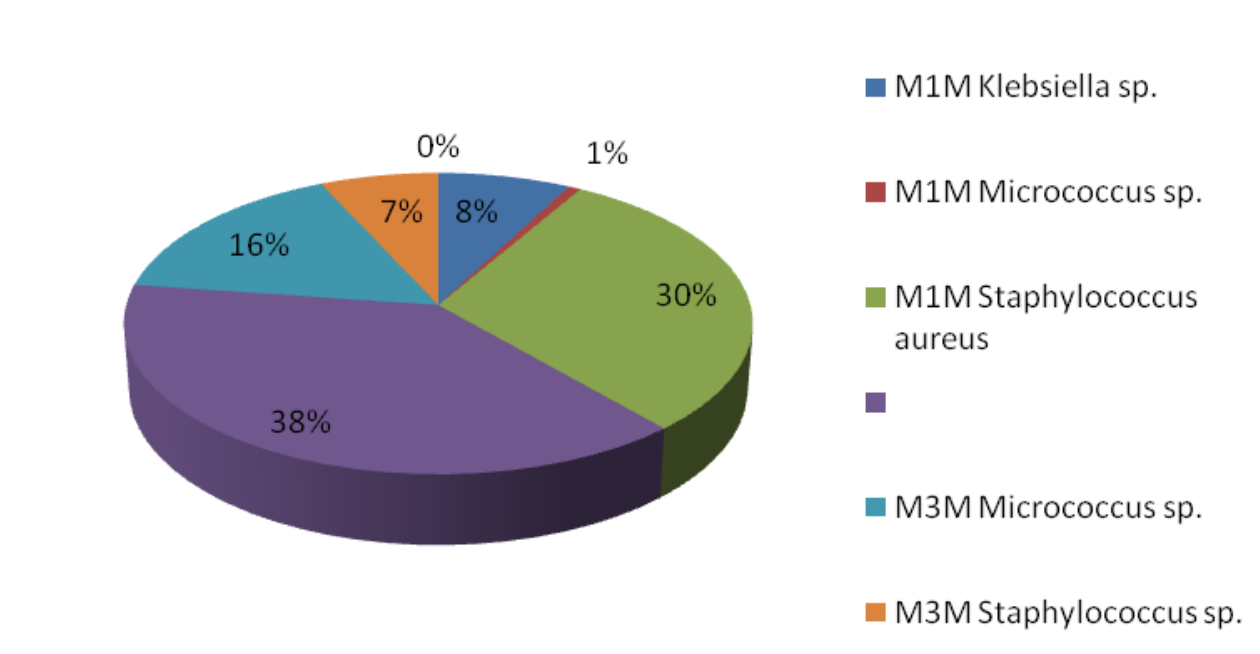

N/B: M1M (Mile 1 Market), M3M (Mile 3 Market)

Figure.2 Prevalence of identified bacteria isolates in the unbranded groundnut oil Samples 

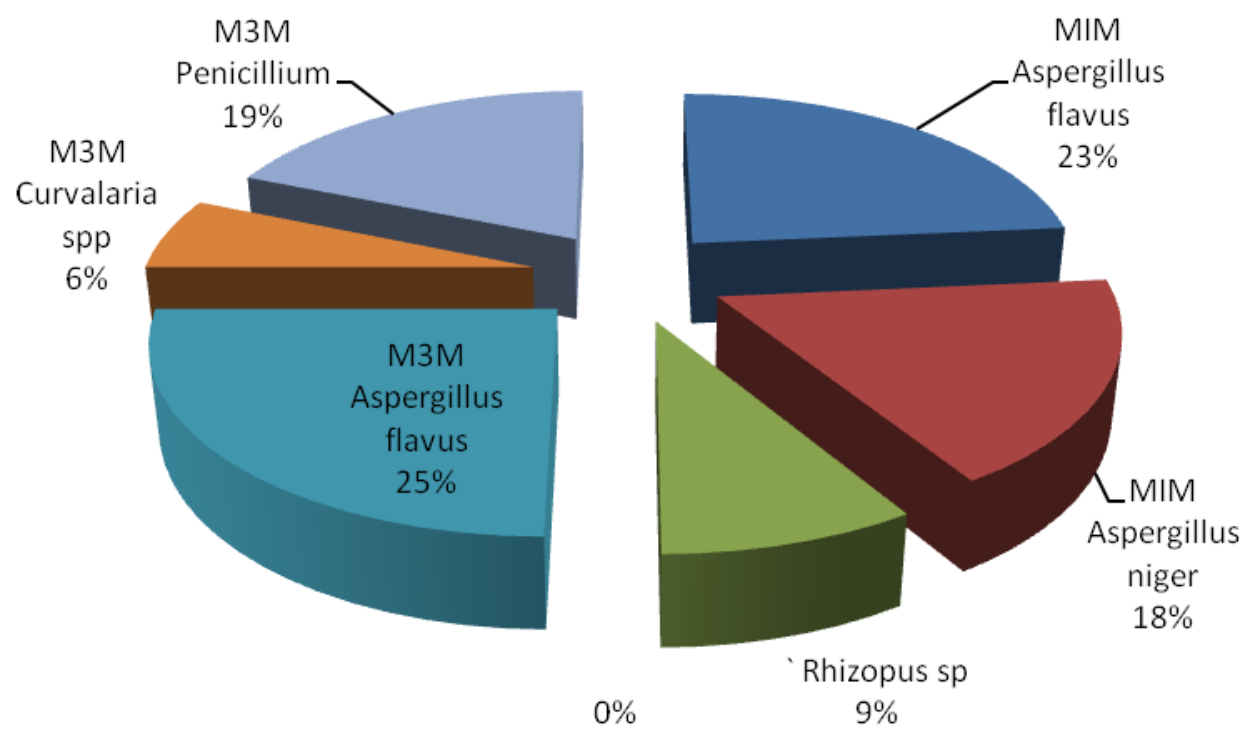

Figure.3 Prevalence of fungi isolates identified in the unbranded groundnut oil samples

The unbranded groundnut oil samples showed growth of both bacteria and fungi species, and the colony counts obtained were high above the recommended limit for edible groundnut oil. The high microbial counts could constitute a public health risks to the numerous consumers. The seeds used for production of groundnut oil should be of good quality and stored under condusive environment.

Localor small scale producers and retailers should be enlightened on the need to adopt Good Manufacturing Practices (GMP), while commercial producers should apply the Hazard Analysis Critical Control Points (HACCP) principles. Public health officials and the regulatory agencies should regularly visit the markets to monitor producers and dispensing of the oil to customers.

\section{References}

ABC Machinery (2019).Peanut Oil Production.www.bestoilmillplant.com/p eanut-oil-production.html. Retrieved, $8 / 11 / 2019$.

Abrunhosa, L., Oliveira, F., Dantas, D., Goncalves, C. and Belo, I. (2013).
Lipases production by Aspergillus

ibericus using Olive oil mill waste water. Bioprocess and Biosystem Engineering, 36: 285-291.

Atasie, V. N., Akinhanmi, T. F. and Ojiodu, C. C. (2009).Proximate analysis and physic-chemical properties of groundnut (Arachishypogaea L.).Pakistan Journal of Nutrition, 8(2): 194-197.

Barku, A. V. Y., Nyarko, H. D. and Dordunu, P. (2012). Studies on physicochemical characteristics, microbial load and storage stability of oil from Indian almond nut (Terminalia catappa L.). Food Science and Quality Management, 12: 9-18.

CDC(2006). Outbreak of Aflatoxicosis in some parts of Africa". Center for Disease Control, Atlanta Georgia, 97(5): 346-352.

Chabiri, S. A., Hati, S. S., Dimari, G. A. and Ogugbuaja, V. O. (2009). Comparative Quality Assessment of branded and unbranded edible vegetable oils in Nigeria. The Pacific Journal of Science and Technology, 10(2): 927-934.

Cheesebrough, M. (2006).District Laboratory Practice in Tropical Countries, Part II. 
Cambridge University Press, Cambridge, UK.pp158-195.

De Hoog, G.S., Guarro, J.G. and Fugureas, M.J. (2000). Atlas of clinical Fungi $2^{\text {nd }}$ ed. (entreat bureauvoor 7 Schimmel cultures/ universitat Rovira I Virgilli, Pp $1-29$

Dubey, R.C. and Maheshwari, D.K. (2003).A

Text Book of Microbiology. Schawd and Company Ltd., Delhi, India: 588-593.

Eshun, G., Amankwah, E. A. and Barimah, J. (2013). Nutrients content and lipid characterization of groundnut of seed pastes of four selected peanut (Arachis hypogaea) varieties from Ghana. African Journal of Food Science, 7(10): 375-381.

Fawole, M. and Oso, B. (1995).Laboratory Manual of Microbiology. First Edition. Spectrum Books limited, Ibadan Nigeria. 34-35.

Flora, O., Oluyemisi, O. E., Olateju, K. S., Mobolaji, O. A. and Adelodun, K. L. (2018). Extent of Microbial Contamination of Refined and Unrefined Vegetable Oils sold in South West Nigeria. Turkish Journal of Agriculture, Food Science and Technology, 6(4): 396-400.

Holt, J.G., Krieg, N.R., Sneath, P.H.A., Stanley, J.T., and Williams, S.T. (1994). Bergey's manual of systematic bacteriology, $9^{\text {th }}$ edn. Williams \& Wilkins Co. Baltimore, Maryland, p. 786.

Ma, F., Wu, R., Li, P. and Yu, L. (2015). Analytical approaches for measuring Pesticides, Mycotoxins and heavy metals in Vegetable Oils: A Review. European Journal of Lipid Science and Technology, 118 (3): 339-352.

Mandloi, S., Radadia, B. B., Visavadia, M. and Vaghela, A. (2014). A Review of Chemical Characteristics (Acid value and Iodine value) of Peanut Oil. Weekly Science Research Journal, 1(30): 1-4.
Manonmani, H. K., Anand, S., Chandrashekar, A. and Rati, E. R. (2005). Detection of aflatoxigenic fungi in selected food commodities by PCR.Process Biochemistry, 40: 28592864.

Nagaranjan, S. (2012).New Tool for Exploring "Old Fiends - Microbial Lipases". Applied Biochemistry and Biotechnology, 168: 1163-1196.

Nkafamiya, I. I., Malina, H. M., Osemeahon, S. A. and Modibbo, U. U. (2010).Percentage oil yield and physiochemical properties of different groundnut species (Arachis hypogaea).

African Journal of Food Science, 4(7): 418-421.

Okechalu,J.N., Dashen,M.M., Manko, P., Okechalu, B. and Gushop, T. J. (2011). Microbiological Quality and Chemical characteristics of Palm Oil sold in Jos Metropolis, Plateau State, Nigeria. Journal of Microbiology and Biotechnology Research, 1(2): 107-112.

Onawo, A. S. and Adamu, M. O. (2018). Microbiological Profile and Quality Assessment of Unbranded Groundnut Oil Marketed as a Major City in Nigeria, Sub-Saharan Africa. Invention Journal of Research Technology in Engineering and Management, 2(1): 36-43.

Sergey, B. (2014). Chemistry: Course Companion. Horner, G., Murphy, B. and Tarcy D. (2014ed). Oxford. London

Sylvester, I. and Elijah, O. J. (2013).Microbiological Quality of crude palm oil produced by smallholder processors in the Niger Delta. Journal of Microbiological and Biotechnology Research, 3(2): 30-36.

Tesfaye, L., Sahile, S. and Madhusudhan, A. (2015). Microbial Quality and Chemical Characteristics Evaluation of Edible Oil Sold at Gondar Town Markets, North West Ethiopia International Journal of Modern Chemistry and Applied Science 
2015, 2(4): 238-247.

Tobin-West, M. D., Dimkpa, S. O. N. and Osakwe, J. A. (2018). Isolation and identification of fungi associated with raw groundnut seeds sold at four major markets in Port Harcourt Metropolis, Rivers State. Journal of Biology, Agriculture and Healthcare, 8 (6): 2224-3208.

Tsuneo, W. (2010). Pictorial atlas of soil and seed fungi: Morphologies of cultural fungi and Key to Species. Third editions, CRC press 2010.

Wali, F., Baloch, M., Nawaz, M. and Khan, K. (2015).Comparison of some physicochemical properties of different available in the local market in Pakistan. International Journal of Recent Research Aspects, 2(2): 93-98.

\section{How to cite this article:}

Austin A. Okwelle and Faith Chinasa Nwabueze. 2020. Microbiological Quality Assessment of Unbranded Groundnut Oil Sold in Major Markets in Port Harcourt City, Rivers State, Nigeria. Int.J.Curr.Microbiol.App.Sci. 9(05): 2964-2974. doi: https://doi.org/10.20546/ijcmas.2020.905.352 